\title{
Investigation of Motivations of Teachers for Participation in Physical Activities
}

\author{
Nuri Muhammet ÇELIK ${ }^{1}$ \\ ${ }^{1}$ School of Physical Education and Sport, Batman University, Batman, Turkey \\ Correspondence: Nuri Muhammet ÇELIK, School of Physical Education and Sport, Batman University, Batman, \\ 72090, Turkey. E-mail: nmcelik@gmail.com
}

Received: May 6, 2020

Accepted: July 9, $2020 \quad$ Online Published: September 25, 2020

doi:10.5539/ies.v13n10p157

URL: https://doi.org/10.5539/ies.v13n10p157

\begin{abstract}
The purpose of this study was to investigate the motivations of high school teachers for participation in physical activities in terms of some variables. The general survey model was employed in the study and 266 teachers from the city center of Batman province of Turkey participated in the study. Personal information form and "the Motivation Scale for Participation in Physical Activity (MSPPA)," which was developed by Tekkurşun and Cicioğlu (2018), were used in the study. The statistical analysis of the data obtained in the study was performed through SPSS 23.00 software and Mann Whitney U and Kruskal Wallis tests, which are two of the non-parametric tests, were applied, as the data did not have a normal distribution. The findings showed that there was no statistically significant difference in terms of the gender variable. However, there was a statistically significant difference in terms of the age variable. This difference was found to be in the environmental factors sub-dimension. At the motivation level, the motivations of the participants for participating in physical activities were found to be high. In conclusion, it can be suggested that the motivations of the participants for participating in physical activities were high and affected by the environmental causes.
\end{abstract}

Keywords: motivation, physical activity, teacher

\section{Introduction}

\subsection{Physical Activity}

The majority of society perceives physical activity as synonymous with the word "sport." However, physical activity is defined as activities that occur with energy consumption using muscles and joints in daily life, increase heart and breathing rate, and result in fatigue with different severities. In addition to sports activities, exercises, games, and various activities done during the day are also considered physical activities. There are four basic areas where individuals can be physically active during the day. These are workplaces, transportation (walking, cycling, etc.), works at home, and leisure activities (Vural et al., 2010; Genç et al., 2002; Şanl1, 2008).

Another definition of physical activity is reported to be any force applied to muscles above the resting level causing energy consumption (Baranowski et al., 1992; Pate et al., 1995).

Physical activity is the type of activities that take place in daily life using muscles and joints causing energy consumption. However, exercise is the planned and repetitive body movements. Lack of physical activity is one of the most important reasons for obesity, against which worldwide struggles continues intensely in recent years obesity emerges as a result of long-term energy imbalance and negatively affects length and quality of life by preparing the way for the occurrence of many diseases. As in the world, the incidence of obesity in our country is increasing steadily while the age of incidence is falling and its effects on health are increasing dramatically (Sevindik, 2011).

Physical activity is defined in three dimensions: Duration (hours-minutes), frequency (how many times per week-month), and intensity (kilojoule or calorie energy consumed per hour or per minute) (Şanl, 2008).

Physical activity is the body movements that create energy expenditure above the resting energy metabolism in the organism as a result of the contraction of skeletal muscles. In other words, physical activity is defined as any body movement that results in energy consumption (Arslan et al., 2003). According to Tamer (1987), physical education, which is expressed as a form of education in which physical activities selected according to human growth, development, and behavior are performed based on movement, is defined as "the transformation of 
physical movements into life according to a planned development" (İnal, 2003).

Physical activity is the consumption of energy by the movement of the body through skeletal muscles. Any kind of physical activity requires energy to be consumed. Physical activity can be demonstrated in different ways according to the characteristics of the studies (can be diversified such as aerobic, anaerobic or static, dynamic). The importance of evaluating physical activity habit is the explanation and interpretation of the word 'physical activity'. Because people believe in the rule of conservation of energy and that all activity fuel is provided by energy composed of food (Zorba et al., 2013).

Physical activity is defined as body movements produced by skeletal muscles that provide a significant increase in energy consumption in addition to resting energy consumption (Vural, 2010).

Lifestyles of people are constantly changing due to the comfort provided by new technological developments, resulting in a decrease in the activities expressed by physical activity. Diseases emerging from this decrease in physical activity also pose a major public health problem. While the most common and death-causing diseases in the 1900s were pneumonia, tuberculosis, and diarrhea, respectively; heart disease, cancer, and stroke (paralysis), which develop due to lack of movement, are on the agenda today. For these reasons, determining the physical activity levels of individuals and directing individuals with low physical activity levels to physical activity is of great importance in terms of community health (Öztürk et al., 2003; Ayhan, 2014).

Physical activity is the sine qua non of any strategy that aims to deal seriously with the problems associated with sedentary life and obesity in children and adults. While active living improves individuals' physical and mental health, it also contributes to social commitment and community well-being. Physical activity is not limited only to sports activities and planned entertainment. Physical activity opportunities are in places where people live and work, in neighborhoods, in educational and health care facilities, in short, everywhere. Physical activity is beneficial for health at any age. It is particularly important for the healthy development of children, young people, and disadvantaged groups. Active aging, on the other hand, can make significant differences in the health of the elderly (Edwards et al., 2006; Şentürk, 2015; Yılmaz, 2017).

\subsection{Physical Activity in Adults}

Physical activity is beneficial to health at any age. Regular physical activity can make significant differences in healthy growth and development of children and young people, prevention of unwanted bad habits, socialization, prevention of various chronic diseases of adults or treatment and support of these diseases, and provision of active old age period for the elderly, in other words, in improving life quality throughout whole life (Tunay, 2008).

A person who pays attention to his/her nutrition in daily life and deals with physical activity, has a positive mental state in addition to his physical health, and as a result, can look at life optimistically because a good physical state improves mental state. Current studies have shown that an active life and regular diet prevent some diseases, and revealed the importance of a healthy diet and physical activity. In most developed countries, physical activity and regular diet are major topics that remain on the agenda. Especially in Western countries, campaigns involving a healthy diet and physical activity are being carried out extensively. During the beginning of physical development, doing sports activities that include especially the development of the bones and pressure is felt (running, soccer, tennis, swimming, etc.) helps strengthen bone density and this affects bone growth. Studies have revealed that individuals who make sports a part of their lives have a long life span that many benefits of doing sports are seen in terms of health, and that also, doing sports has a decisive effect on the development of socialization between people (Gümüş, 2009; Ayhan, 2014).

It is very important for the health of the individuals to gain the habit of regular exercise starting from their childhood and make exercise a part of their lives. Physical activity performed on certain days of the week, even if it is not done daily, has great importance in protecting individual health and preventing health problems that may be experienced in the time ahead. In today's world, technological advances continue to place people in a sedentary life, and therefore a sedentary life increasingly engulfs people. Urban lifestyle and technological developments reduce physical activity and young people tend to have sedentary lifestyles such as surfing on the Internet, watching television, and playing games in cafes. This causes their sedentary times to increase. Therefore, the sedentary lifestyle plays a leading role in causing many musculoskeletal diseases such as coronary heart diseases, high blood pressure, diabetes, obesity, and breast cancer (Özarslan, 2015).

\subsection{The Notions of Physical Activity and Exercise}

Physical activity can be expressed in different ways as "the sum of movements displayed through skeletal muscles during daily functions" and as the whole body movements that result in energy expenditure by skeletal muscles (Robison \& Miller, 2004; Pitta et al., 2006). The concept of physical activity is publicly thought to be the same as 
the concept of "sport" and "exercise". However, physical activity is defined as the activities that are occurred through energy consumption using muscles and joints within the daily process and result in different levels of tiredness through increased heart and breathing rate (Bayrakçı, 2008). Activities such as climbing upstairs, playing games, skating, dancing, housework, cycling and walking for transportation, and shopping are considered as part of physical activity (Fox \& Page, 2001). Although the concepts of physical activity and exercise have different definitions, they are often used interchangeably (Caspersen et al., 2000). Exercise is an activity that is structured, planned and must be repeated in order to maintain, improve or achieve physical fitness, and it is the lower step of the physical activity (Haskell \& Kiernan, 2000). The physical activity is classified as light, medium, or heavy according to the MET (metabolic equivalence) value. MET is a measure of oxygen spent or consumed per kilogram in the unit time. 1 MET corresponds to the amount of oxygen consumed during a rest (approximately 3.5 $\mathrm{ml} / \mathrm{kg} /$ minute) (Saygın, 2003; Tümer, 2007).

\subsection{The Relationship Among Physical Activity, Exercise, and Health}

Studies on the benefits of regular physical exercise since the early 1950s have indicated that exercise is beneficial in protecting and improving health and preventing diseases (Tümer, 2007). In the 1960s, when long-term space travel began, studies were carried out to examine the changes caused by the gravity-free and motionless living conditions encountered by humans. Simultaneously, the studies were accelerated as the inactivity was seen as one of the cardiovascular risk factors throughout the world and the subject gained more importance (Sevim, 2002).

The American College of Sports Medicine published a guide in 1978 for individuals, who wanted to exercise, highlighting that increasing the heart rate by $60 \%$ to $90 \%$ with duration of $15-60$ minutes for 3-5 times a week improves health. The World Health Organization reported that a healthy life would be achieved by performing regular and moderate physical activity at least 5 days a week or each day for 30 minutes (Tümer, 2007). Studies reporting that exercise is a positive health behavior started to be conducted in higher numbers in the 1980s. Medical studies conducted in these years indicated that risk factors in cardiovascular diseases decrease with exercise. In the same period, studies started to be conducted examining the relationships between blood pressure and physical activity levels, body mass index and cholesterol levels, and it was widely accepted that gender, age, educational status, health status, physical activity and psychosocial variables affect the physical activity level (Callahan, 2004; Tümer, 2007). By the year 2000, in line with the national health goals of the United States called as "Healthy People 2000", a new standpoint has been gained by explaining that exercise improves the quality of life, prevents diseases and injuries, as well as decreases the mortality rate (Tümer, 2007). Long-term studies have shown that exercise positively affects health in adults and that regular exercise is beneficial in all age groups (Ainsworth et al., 1993; Rowlands et al., 1999; Ocak and Tortop, 2013). Regular participation in moderate-intensity physical activities increases speed development, bone density, endurance, flexibility, muscular strength and cardiorespiratory endurance (Greendale et al., 1995), decreasing the possibility of high-level anxiety, depression and obesity. People, who exercise, are less likely to develop and die from diseases such as colon cancer, cardiovascular disease, Type-2 diabetes and high blood pressure compared to their peers, who do not exercise (Longnecker et al., 1995; Haapanen et al., 1996).

Numerous studies are being conducted today revealing the positive relationship between health and physical activity. Researchers have agreed on a common ground that despite this positive relationship, people do not exercise enough. Decreasing level of physical movement is increasingly threatening the health of people all over the world. The World Health Organization reports that more than $60 \%$ of the world's population adopts a sedentary lifestyle that causes health problems. Of the 135 million diabetes patients worldwide, $90 \%$ are the patients of Type- 2 diabetes caused by lack of movement. Experts investigating this situation believe that $60 \%$ of all diseases by 2020 will be caused by non-communicable diseases and $73 \%$ of the deaths will be caused by lack of movement. This increase in health problems naturally increases health expenses. There are also studies indicating that increasing costs of the health services around the world can also have economic benefits such as increasing the number of individuals, who exercise regularly, decreasing health expenses and increasing effectiveness. According to Bedard, an increase from $21 \%$ to $37 \%$ in the proportion of individuals, who exercised regularly to reduce the risk of heart disease between 1981-1995, saved \$ 190 million in health expenses in Canada in 1995 (Aç1l, 2006).

\section{Motivation}

The origin of the word motivation is based on the Latin word movere which means to move. In Turkish, 'güdü' or 'motiv' can be expressed as motive or motivator (Durmaz 2006). Motivation is the instinctive state that initiates, drives, and sustains the movement. Motivation can be seen as an inner helping power of an individual to achieve his/her goal, or as an energy that is psychologically formed in his/ her head (Sternberg et al., 2002). One of the basics of motivation is "what causes behavior." As a result, motivation is seeking a solution for the results that will 
occur when starting a job, continuing, changing, and moving towards the goal. Another basis is "what causes the change in intensity of behavior". Behaviors differ for an individual and among individuals. Motivational research explores the power of behavior and the situations and experiences during orientation to this behavior (Reeve, 2001). The point is that an individual should be able to understand and tell if new information he /she gets is consistent or not with his/her existing knowledge through the effort to focus on the subject, true learning, and the notion of communicating correctly. It is the thinking of the individual on what he/she sees, hears, and does. This kind of cognitive movement determines the benefits of higher-level motivation (Ormrod, 1999). Motivation refers to the installation of internal and external forces that lead to the initiation, orientation, focus, and maintenance of behavior (Viau, 2015). Motivation is one of the important factors affecting lifelong learning. Individuals need to be motivated and keep their motivation high in order to overcome the obstacles they face throughout life and to continue the learning process. It is especially important that schools be organized in ways that motivate their students. Motivation can be achieved in three ways: goal-centered, activity-centered, and learning-centered. The first is the individual's focus on the goal, the second is the willingness to participate in activities, and the third is the desire to reach information (Günüç et al., 2012). As can be understood from the definitions, motivation can be said to be one of the effective factors in participation in physical activities and continuing it. The study aimed to examine the motivations of high school teachers to participate in physical activities in terms of age and gender variables.

The concept of motivation refers to the configuration of internal and external forces that lead to the initiation, orientation, focus and maintenance of a behavior (Budak, 2015). Motivation is one of the important factors affecting lifelong learning. Individuals need to be motivated and keep their motivation high in order and to continue the learning process and to overcome the obstacles they face throughout their lives. It is of particular importance that schools are organized in a way that motivates their students. Motivation can be achieved in three ways: goal-centered, activity-centered, and learning-centered. The first is the student's focus on the goal, the second is the willingness to participate in activities, and the third is the desire to reach information (Günüç et al., 2012).

\subsection{What Are the Factors Affecting Motivation?}

The motivation of a student and teacher is influenced from numerous factors, which can be grouped as: background of the student and the teacher (family, friends, areas of interest etc.), the society one lives in (values, laws, culture etc.), school (curriculum, course hours etc.), classroom (educational activities, teacher evaluations, classroom climate, awards and sanctions etc.) (Budak, 2015).

\section{Method}

\subsection{Research Model}

In this study, the survey model was used that is one of the descriptive research methods. Survey models are arrangements made on a group of samples taken from the entire population in order to make a general judgment about the population in an environment consisting of a large number of elements (Karasar, 2005).

\subsection{The Population and the Sample}

The population of the study is comprised of 50 high schools in Batman province of Turkey and the sample group is comprised of 266 teachers from 30 high schools.

\subsection{Data Collection Tools}

The personal information form, developed by the authors, and "the Motivation Scale for Participation in Physical Activity (MSPPA)," developed by Tekkurşun and Cicioğlu (2018), were used in the study. The motivation levels of the participants to participate in physical activity were compared in terms of age and gender.

\subsection{The Motivation Scale for Participation in Physical Activity (MSPPA)}

Consisting of 3 sub-dimensions, namely individual causes, environmental causes, and non-causality and 16 items, the 5- point Likert- type scale aims to measure the motivations for participation in physical activity. The lowest score that can be taken from the scale is 16 and the highest is 80 . The scores received from the MSPPA indicating the level of participants motivations to participate in physical activity are grouped as 1-16 (very low), 17-32 (low), 33-48 (medium), 49-64 (high), and 65-80 (very high). Higher scores of the participants mean that their motivations to participate in physical activity are positive. As for the reliability coefficient of the scale; individual causes consisted of $1^{\text {st }}, 2^{\text {nd }}, 3^{\text {rd }}, 4^{\text {th }}, 5^{\text {th }}$, and $6^{\text {th }}$ items, and their explained variance being 25.53 and Cronbach Alpha .89 . The environmental causes factor consisted of $10^{\text {th }}, 11^{\text {th }}, 12^{\text {th }}, 13^{\text {th }}$, and $14^{\text {th }}$ items, and the variance ratio they explained is 20.52 and Cronbach Alpha .86 . The non-causality factor consisted of $15^{\text {th }}, 16^{\text {th }}, 17^{\text {th }}$, and $18^{\text {th }}$ items, 
and, the variance ratio explained is 8.62 and Cronbach Alpha .82 .

\subsection{Data Analysis}

Statistical analysis of the data obtained in the study was conducted in SPSS 23.00 software. In the analysis of the data, descriptive statistics, Shapiro-Wilk, and Kolmogorov Smirnov normality tests were performed and because the data did not show normal distribution, two of the non-parametric tests Mann Whitney U and Kruskal Wallis tests were applied. The significance level for the comparisons was 0.05 .

\section{Findings}

Table 1. Distributions of the Participants by Percentage and Frequency

\begin{tabular}{cccc}
\hline Variables & & $\mathrm{N}$ & $\%$ \\
\hline \multirow{2}{*}{ Age } & $18-30$ & 148 & 55.6 \\
\cline { 2 - 4 } & $31-60$ & 118 & 44.4 \\
\hline \multirow{2}{*}{ Gender } & Female & 109 & 41.0 \\
\cline { 2 - 4 } & Male & 157 & 59.0 \\
\hline Total & & 266 & 100 \\
\hline
\end{tabular}

Table 1 shows that 148 females-males (55.6\%) were in the age range of (18-30) and 118 females-males (44.4\%) were in the age range of (31-60). In the study with a total of 266 participants, the numbers of females and males were found to be $109(41 \%)$ and $157(59 \%)$, respectively.

Table 2. Mann Whitney U test results of the participants by variables

\begin{tabular}{|c|c|c|c|c|c|c|c|}
\hline & & & & & & & \\
\hline & & & $\mathrm{n}$ & Mean Rank & Total Rank & $\mathrm{U}$ & $\mathrm{P}$ \\
\hline \multirow{2}{*}{ Individual Causes } & \multirow{6}{*}{ Age } & $18-30$ & 148 & 139.12 & 20590.00 & \multirow{2}{*}{7900.000} & \multirow{2}{*}{.178} \\
\hline & & $31-60$ & 118 & 126.45 & 14921.00 & & \\
\hline \multirow{2}{*}{ Environmental Causes } & & $18-30$ & 148 & 147.55 & 21838.00 & \multirow{2}{*}{6652.000} & \multirow{2}{*}{.001} \\
\hline & & $31-60$ & 118 & 115.87 & 13673.00 & & \\
\hline \multirow{2}{*}{ Non-causality } & & $18-30$ & 148 & 130.32 & 19287.00 & \multirow{2}{*}{8261.000} & \multirow{2}{*}{.446} \\
\hline & & $31-60$ & 118 & 137.49 & 16224.00 & & \\
\hline \multirow{2}{*}{ Individual Causes } & \multirow{7}{*}{ Gender } & Female & 109 & 134.14 & 14621.50 & \multirow{2}{*}{8486.500} & \multirow{2}{*}{.909} \\
\hline & & Male & 157 & 133.05 & 20889.50 & & \\
\hline \multirow{2}{*}{ Environmental Causes } & & Female & 109 & 139.90 & 15249.50 & \multirow{2}{*}{7858.500} & \multirow{2}{*}{.257} \\
\hline & & Male & 157 & 129.05 & 20261.50 & & \\
\hline \multirow{3}{*}{ Non-causality } & & Female & 109 & 130.83 & 14260.50 & \multirow{3}{*}{8265.500} & \multirow{3}{*}{.634} \\
\hline & & Male & 157 & 135.35 & 21250.50 & & \\
\hline & & No & 109 & 134.14 & 14621.50 & & \\
\hline
\end{tabular}

${ }^{*} \mathrm{P}<0.05$.

Table 2 shows that there was no significant difference in individual causes and non-causality sub-dimensions according to the age variable. However, there was a significant difference in the environmental causes sub-dimension. This difference was observed to be in the teachers aged between 18-30. There was no significant difference in sub-dimensions regarding the reasons affecting the motivations of the teachers to participate in physical activity according to the gender variable.

Table 3. Mean motivations of the participants

\begin{tabular}{cccccc}
\hline & $\mathrm{N}$ & Min. & Max. & Mean & Standard Deviation \\
\hline Motivation & 266 & 33.00 & 80.00 & 51.18 & 6.491 \\
\hline
\end{tabular}

In Table 3, of the 266 participants in the study, the lowest motivation score for participation in physical activity was 33.00 and the highest motivation score was 80.00 . In the scale, the scores of 1-16 show that the participants have a very low motivation for participation in physical activity, 17-32 low, 33-48 medium, 49-64 high, and 65-80 very 
high. In this sense, the participants' mean score was 51.18 and the standard deviation was 6.491 , indicating that the participants had a high level of motivation to participate in physical activity.

\section{Discussion}

Physical activity and exercise are of steadily increasing importance in the world. In our country, as in many countries, conditions such as irregular diet and malnutrition, environmental factors, and individual factors are among the main problems that prevent participation in physical activities. Our study conducted for this purpose was examining the motivations of high school teachers, who are also role models for the young besides education and training, for participation in physical activities.

King et al. (2008) revealed that people who received support from family and friends for participation in physical activities lead a more active life. Alemdağ and Öncü (2015) found that candidates of teachers interested in sports in their families played a more active role in participating in physical activities. On the other hand, some of the participants stated that they did not receive enough family support for various reasons. Bentley et al. (2012) and Kahn et al. (2008) also highlighted the need to raise awareness of families about participation in physical activities. Anderson et al. (2009) found that having family in a supportive role was effective in making children exercise regularly and have positive attitudes towards sports. Dalaman (2015), Öncü et al. (2012), and Alemdag et al. (2014) stated that the attitudes of teachers who regularly exercised towards physical education and game teaching class were more positive than those who did not exercise regularly. Examining the relationship between doing active sports under a license before or during profession of classroom teachers in association with their formation levels for educational game teaching and practice, Tortop et al. (2010) found that there was a statistically significant difference, and that doing active sports before and during the professional life of classroom teachers had a positive effect on their formation levels for educational game teaching and practice. As can be understood from the mentioned studies, we can say that the participation of teachers in physical activities have positive effects.

In a study conducted on university students examining the effect of gender on exercise and participation in sports, Kilpatrick et al. (2005) found that gender had significant effects over five motivation variables. Women rated significantly higher than men in weight management as a motivational factor. In contrast, men indicated higher levels of motivation than women in difficulty, competition, social appreciation, strength, and endurance. Competition had the biggest gender impact among the five motivational factors. The results of this study suggest that men are more likely to be motivated by factors that can be described as ego-related motivations.

A study conducted by Cengiz (2007) in Middle Eastern Technical University (METU) indicates that the physical activity levels of male students (25.2\%) are higher than female students (15.6\%). Many studies on this subject have shown significant differences between the participation levels of males and females in physical activities (Ebem, 2007; Cook et al., 2006; Crocker et al., 2000; Hayer et al., 1999; Hagger et al., 1998; Ross \& Pate, 1987).

In a study conducted by Brown et al. (2003) on prep students at the university, it was determined that there was a significant difference between the physical activity levels of male and female students. This difference between female and male students may be due to the fact that families are more conservative in directing females to sports. In addition, the motive behind this difference might be explained as the inadequate social and sports facilities in the university where the research was conducted or the fact that it allows males to play sports rather than females.

In our study, there was no significant difference in sub-dimensions regarding the reasons affecting the motivation of the teachers involved in physical activities according to gender variables. According to the age variable, there was no significant difference in the individual causes and non-causality sub-dimensions. However, participants were found to have a high level of motivation to participate in physical activities. Şanlı and Güzel (2008) reported in their study on the relationship between physical activity levels and age, gender, and body mass index in teachers that the physical activity levels of the male teachers were higher than those of female teacher and again, in their study on 286 teachers, they reported that the teachers had moderate physical activity levels. There are studies in that the level of participation in physical activities differs significantly in favor of males according to the gender variable, as well as studies that differ in favor of women. Karaca (2008) found that women prefer moderate-intensity activities while men prefer high-intensity activities. Vassigh (2012) found that regular exercise is more common in men than in women. Kalkavan et al. (2016) stated that women spend physically active time more than men. However, many studies have found that men have higher levels of physical activity than women (Kara, 2006; Şanlı \& Güzel, 2009; Erdoğan et al., 2011; Ölçücü et al., 2015; Kızar et al., 2016). We can suggest that gender cannot be generalized in participation in physical activities because there is no significant difference in terms of gender variable in our study and there are results in favor of both men and women in other studies.

In our study, we found a statistically significant difference considering the age variable. There was a significant difference in the environmental causes sub-dimension in the group of 18-30 age group. At the motivation level, it 
was determined that participants had a high level of motivation for participating in physical activities. In their study, Türkeli and Namlı (2019) found that the age variable did not affect the motivation for participation in physical activities. Gümüş et al. (2017) stated in their studies that the participants' selection of the place of physical activity showed no significant difference in gender, marital status, and age, however, there was a significant difference in marital status and age regarding the reasons that prevent their participation in physical activities. On the contrary, it has been determined in the literature that the state of being active for recreational purposes is higher at young ages (Yalçin et al., 2017). This result is similar to the findings of our research. The significant difference in environmental causes in the age group of 18-30 may be thought to be due to environmental factors that influence the individual to perform the activity.

In conclusion, we can say that participants had high motivations to participate in physical activities and that environmental causes were effective in the 18-30 age group.

\subsection{Recommendations}

In our study, we found that high motivation levels of teachers for participation in physical activities increased owing to environmental reasons depending on the age variable. For this reason, in order to raise the motivation levels of teachers in terms of social and psychological aspects, certain actions should be taken concerning their environments; such as the elimination of factors that prevent teachers from participating in physical activities, building sufficient number of sports facilities (swimming, fitness, etc.), creation of recreational areas such as active living and physical activity areas, and providing active life spaces in the physical environments such as bicycle paths and hiking trails by the municipalities.

\section{References}

Açıl, A. A. (2006). Şizofrenik Hastalarda Fiziksel Egzersizin Ruhsal Durum Ve Yaşam Kalitesi Üzerine Etkisi, Cumhuriyet Üniversitesi, Sağllk Bilimleri Enstitüsü. Hemşirelik Programı, Yüksek Lisans Tezi, Sivas.

Ainsworth, B. E., Haskell, W. L., Leon, A. S., Jacobs Jr., D. R., Montoye, H. J., Sallis, J. F., \& Paffenbarger Jr., R. S. (1993). Compendium of physical activities: classification of energy costs of human physical activities. Medicine and science in sports and exercise, 25(1), 71-80. https://doi.org/10.1249/00005768-199301000-00011

Alemdağ, S., \& Öncü, E. (2015). The investigation of participation physical activity and social appearance anxiety at the preservice teachers. International Journal of Science Culture and Sport, 3, 278-300.

Alemdağ, S., Öncü, E., \& Sakallığlu, F. (2014). Sınıf öğretmeni adaylarının beden eğitimi dersine yönelik tutum ve öz-yeterlikleri. Abant İzzet Baysal Üniversitesi Eğitim Fakültesi Dergisi, 14(2), 45-60. https://doi.org/10.17240/aibuefd.2014.14.2-5000091527

Anderson, C. B., Hughes, S. O., \& Fuemmeler, B. F. (2009). Parent-child attitude congruence on type and intensity of physical activity: Testing multiple mediators of sedentary behavior in older children. Health psychology, 28(4), 428. https://doi.org/10.1037/a0014522

Arslan, C., Koz, M., Gür, E., \& Mendeş, B. (2003). Üniversite öğretim üyelerinin fiziksel aktivite düzeyleri ve sağlık sorunları arasındaki ilişkinin araştııılması. F. Ü. Sağlık Bilimleri Dergisi, 17(4), 249-258.

Aşçı, F. H., Tüzün, M., \& Koca, C. (2006). An examination of eating attitudes and physical activity levels of Turkish university students with regard to self-presentational concern. Eating Behaviors, 7(4), 362-367. https://doi.org/10.1016/j.eatbeh.2005.11.011

Ayhan, Y. F. (2014). Çocukluk ve Ergenlik Dönemindeki Fiziksel Aktivite Deneyimleri İle Yetişskinlikteki Fiziksel Aktivite Düzeyleri Ve Beden Kompozisyonlarının İncelenmesi (Yüksek Lisans Tezi). Muğla.

Baranowski, T., Bouchard, C., Bar-Or, O., Bricker, T., Heath, G., Kimm, S. Y. S., ...Washington, R. (1992). Assesment, Prevalence and Cardiovascular Benefits of Physical Activity and Fitness in Youth. Official Journal of the American College of Sports Medicine, 24(6), 237-247. https://doi.org/10.1249/00005768-199206001-00006

Bayrakçı, T. V. (2008). Yetişskinlerde Fiziksel Aktivite. 1. Baskı., Ankara. Sağlık Bakanlığı Yayını, Şubat.

Bentley, G. F., Goodred, J. K., Jago, R., Sebire, S. J., Lucas, P. J., Fox, K. R., ... \& Turner, K. M. (2012). Parents' views on child physical activity and their implications for physical activity parenting interventions: a qualitative study. BMC pediatrics, 12(1), 1-9. https://doi.org/10.1186/1471-2431-12-180

Brown, D. W., Balluz, L. S., Heath, G. W., Moriarty, D. G., Ford, E. S., Giles, W. H., \& Mokdad, A. H. (2003). Associations between recommended levels of physical activity and health-related quality of life Findings 
from the 2001 Behavioral Risk Factor Surveillance System (BRFSS) survey. Preventive medicine, 37(5), 520-528. https://doi.org/10.1016/S0091-7435(03)00179-8

Callaghan, P. (2004). Exercise: a neglected intervention in mental health care? Journal of psychiatric and mental health nursing, 11(4), 476-483. https://doi.org/10.1111/j.1365-2850.2004.00751.x

Caspersen, C. J., Pereira, M. A., \& Curran, K. M. (2000). Changes in physical activity patterns in the United States, by sex and cross-sectional age. Medicine \& Science in Sports \& Exercise, 32(9), 1601-1609. https://doi.org/10.1097/00005768-200009000-00013

Cengiz, C. (2007). Physical Activity and Exercise Stages of Change Levels of Middle East Technical University Students [Bilim Uzmanlığı Tezi]. Middle East Technical University, Ankara.

Crocker, P. R., Eklund, R. C., \& Kowalski, K. C. (2000). Children's physical activity and physical self-perceptions. Journal of sports sciences, 18(6), 383-394. https://doi.org/10.1080/02640410050074313

Dalaman, O. (2015). Sınıf öğretmeni adaylarının "Beden Eğitimi ve Oyun Öğretimi” dersine yönelik tutumlarının değişik faktörlerce incelenmesi. Mehmet Akif Ersoy Üniversitesi Eğitim Fakültesi Dergisi, 36, 59-71.

Durmaz. (2006). Kişilerarası İletişim ve Motivasyon. Ege Üniversitesi Yayınları İletişim Fakültesi Yayın, 17(3), 93.

Ebem, Z. (2007). Health promoting behaviors and exercise stages of change levels of students at transition to university (Unpublished $\mathrm{PhD}$ thesis). Middle East Technical University Social Sciences Institute, Ankara.

Edwards, P., \& Tsouros, A. (2006). Kentsel Çevrede Fiziksel Aktivite ve Aktif Yaşamın Desteklenmesi. Bilimsel Kanitlar, Dünya Sağlik Örgütü.

Erdoğan, M., Certel, Z., \& Güvenç, A. (2011). Masa Başı Çalışanlarda Fiziksel Aktivite Düzeyi: Obezite ve Diğer Özelliklere Göre İncelenmesi (Akdeniz Üniversitesi Tıp Fakültesi Hastanesi Örneği). Spor Hekimliği Dergisi, 46, 97-107.

Fox, K. R., \& Page, A. (2001). The Management of obesity and related disorders. EDT: Kopelman PG, Martin Dunitz, 179-201.

Genç, M., Eğri, M., Kurçer, M. A., Kaya, M., Pehlivan, E., Karaoğlu, L., \& Güneş, G. (2010). Malatya Kent Merkezindeki Banka Çalışanlarında Fizik Aktivite Sıklığı. Journal of Inonu University Medical Faculty, 9(4), 237-240.

Greendale, G. A., Barrett-Connor, E., Edelstein, S., Ingles, S., \& Haile, R. (1995). Lifetime leisure exercise and osteoporosis the Rancho Bemardo Study. American journal of epidemiology, 141(10), 951-959. https://doi.org/10.1093/oxfordjournals.aje.a117362

Gümüş, H. (2009). Yetiştirme Yurtlarında Kalan Adolesanların Beslenme Ve Fiziki Aktivite Durumlarının Sağllk Ve Vücut Kompozisyonları İle İlişsisinin Saptanması. Yayınlanmamış Doktora Tezi. Gazi Üniversitesi Eğitim Bilimleri Enstitüsü Ev Ekonomisi Bölümü Aile Ekonomisi Ve Beslenme Eğitimi Anabilim Dalı. Ankara.

Gümüş, H., Özgül, S. A., \& Karakılıç, M. (2017). Fiziksel Aktivite için Park ve Rekreasyon Alanlarına Gelen Kullanıcıların Mekân Seçimini ve Fiziksel Aktiviteye Katılımını Etkileyen Faktörler. Spormetre, 15(1), 31-38. https://doi.org/10.1501/Sporm_0000000305

Günüç, S., Odabaşı, H. F., \& Kuzu, A. (2012). Yaşam Boyu Öğrenmeyi Etkileyen Faktörler. Gaziantep University Journal of Social Sciences, 11(2).

Haapanen, N., Miilunpalo, S., Vuori, I., Oja, P., \& Pasanen, M. (1996). Characteristics of leisure time physical activity associated with decreased risk of premature all-cause and cardiovascular disease mortality in middle-aged men. American Journal of Epidemiology, 143(9), 870-880. https://doi.org/10.1093/oxfordjournals.aje.a008830

Hagger, M., Ashford, B., \& Stambulova, N. (1998). Russian and British children's physical self-perceptions and physical activity participation. Pediatric Exercise Science, 10(2), 137-152. https://doi.org/10.1123/pes.10.2.137

Haskell, W. L., \& Kiernan, M. (2000). Methodologic issues in measuring physical activity and physical fitness when evaluating the role of dietary supplements for physically active people. The American journal of clinical nutrition, 72(2), 541S-550S. https://doi.org/10.1093/ajen/72.2.541S 
Hayes, S. D., Crocker, P. R., \& Kowalski, K. C. (1999). Gender differences in physical self-perceptions, global self-esteem and physical activity: Evaluation of the physical self-perception profile model. Journal of Sport Behavior, 22(1), 1.

İnal, N. A. (2003). Beden Eğitimi Ve Spor Bilimi. Ankara, Nobel Yayın Dağıtım

Kahn, J. A., Huang, B., Gillman, M. W., Field, A. E., Austin, S. B., Colditz, G. A., \& Frazier, A. L. (2008). Patterns and determinants of physical activity in US adolescents. Journal of Adolescent Health, 42(4), 369-377. https://doi.org/10.1016/j.jadohealth.2007.11.143

Kalkavan, A., Özkara, A. B., Alemdağ, C., \& Çavdar, S. (2016). Akademisyenlerin Fiziksel Aktiviteye Katılım Düzeyleri ve Obezite Durumlarının İncelenmesi. International Journal of Science Culture and Sport, 4(1), 329-339.

Kara, D. (2006). Sporun Topluma Yaygınlaştırılmasında Sosyo Ekonomik Faktörlerin Araştırılması (Niğde İli Örneği). Yüksek lisans Tezi, Niğde Üniversitesi, Sosyal Bilimler Enstitüsü. Niğde.

Karaca, A. (2008). Yetişkin bireylerde orta ve yüksek şiddetli fiziksel aktivitenin cinsiyete göre incelenmesi. Hacettepe Spor Bilimleri Dergisi, 9(1), 54-62.

Karasar, N. (2005). Bilimsel araştırma yöntemi. 15. Baskı. Ankara: Nobel Yayın Dağııım.

Kilpatrick, M., Hebert, E., \& Bartholomew, J. (2005). College students' motivation for physical activity: differentiating men's and women's motives for sport participation and exercise. Journal of American college health, 54(2), 87-94. https://doi.org/10.3200/JACH.54.2.87-94

King, K. A., Tergerson, J. L., \& Wilson, B. R. (2008). Effect of social support on adolescents' perceptions of and engagement in physical activity. Journal of Physical Activity and Health, 5(3), 374-384. https://doi.org/10.1123/jpah.5.3.374

Kızar, O., Kargün, M., Togo, O. T., Biner, M., \& Pala, A. (2016). Üniversite Öğrencilerinin Fiziksel Aktivite Düzeylerinin İncelenmesi. Marmara Üniversitesi Spor Bilimleri Dergisi, 1(1), 63-74. https://doi.org/10.22396/sbd.2016.6

Longnecker, M. P., De Verdier, M. G., Frumkin, H., \& Carpenter, C. (1995). A case-control study of physical activity in relation to risk of cancer of the right colon and rectum in men. International journal of epidemiology, 24(1), 42-50. https://doi.org/10.1093/ije/24.1.42

Ocak, Y., \& Tortop, Y. (2013). Kadınlarda Halk Oyunları Çalışmalarının Bazı Fiziksel Uygunluk Parametreleri Üzerine Etkisinin İncelenmesi. Spor Ve Performans Araştırmaları Dergisi, 4(1), 46-54.

Ölçücü, B., Vatansever, Ş., Özcan, G., Çelik, A., \& Pektaş, Y. (2015). Üniversite Öğrencilerinde Fiziksel Aktivite Düzeyi ile Depresyon ve Anksiyete İlişkisi. Uluslararası Türk Eğitim Bilimleri Dergisi, 3(4), 58-67.

Öncü, E., \& Cihan, H. (2012). Sınıf öğretmeni adayları için beden eğitimi dersi tutum ölçeğinin geliştirilmesi. Dicle Üniversitesi Ziya Gökalp Eğitim Fakültesi Dergisi, 18, 31-47.

Ormrod, J. E. (1999). Human Learning (3rd ed.). Prentice-Hall, Inc., USA.

Özarslan, S. (2015). Gülhane Askeri Tup Fakültesi ve Hemşirelik Yüksekokulu öğrencilerinin fiziksel aktivite düzeylerinin çeşitli değişkenler açısından incelenmesi (Master's thesis, Kütahya Dumlupınar Üniversitesi/Sağlık Bilimleri Enstitüsü).

Öztürk, M., Avcı, S., \& Ataman, B. H. (2003). İstanbul Üniversitesi Öğretim Elemanlarının Unvanlarına ve Meslek Gruplarına Göre Fiziksel Aktivite Düzeylerinin İncelenmesi. İ.Ü.Spor Bilim Dergisi, 11(3), 183-187.

Pate, R. R., Pratt, M., Blair, S. N., Haskell, W. L., Macera, C. A., Bouchard, C., ... \& Kriska, A. (1995). Physical activity and public health: A recommendation from the Centers for Disease Control and Prevention and the American College of Sports Medicine. Jama, 273(5), 402-407. https://doi.org/10.1001/jama.1995.03520290054029

Pitta, F., Troosters, T., Probst, V. S., Spruit, M. A., Decramer, M., \& Gosselink, R. (2006). Quantifying physical activity in daily life with questionnaires and motion sensors in COPD. European respiratory journal, 27(5), 1040-1055. https://doi.org/10.1183/09031936.06.00064105

Reeve, J. (2001). Understanding Motivation and Emotion (3rd ed.). John Wiley \& Sons, Inc, USA.

Robison, J., \& Miller, W. C. (2004). Exercise, physical activity, weight and health. Health at Every Size, 18(4), 49-50. 
Ross, J. G., \& Pate, R. R. (1987). The National Children And Youth Fitness Study II: A Summary Of Findings. Journal of Physical Education, Recreation and Dance, 58, 51-56. https://doi.org/10.1080/07303084.1987.10604374

Rowlands, A. V., Eston, R. G., \& Ingledew, D. K. (1999). Relationship between activity levels, aerobic fitness, and body fat in 8-to 10-yr-old children. Journal of Applied Physiology, 86(4), 1428-1435. https://doi.org/10.1152/jappl.1999.86.4.1428

Şanl, E., \& Güzel A. N. (2008). Öğretmenlerde fiziksel aktivite düzeyi-yaş, cinsiyet ve beden kitle indeksi ilişkisi. Yüksek Lisans Tezi. Gazi Üniversitesi Eğitim Bilimleri Enstitüsü, Ankara.

Şanlı, E., \& Güzel, N.A. (2009). Öğretmenlerde Fiziksel Aktivite Düzeyi -Yaş, Cinsiyet ve Beden Kitle İndeksi İlişkisi, Gazi Beden Eğitimi ve Spor Bilimleri Dergisi, 3, 23-32.

Saygın, Ö. (2003). 10-12 Yas Çocukların Fiziksel Aktivite Düzeyleri Ve Fiziksel Uygunluklarının Incelenmesi. M.Ü. Sağlık Bilimleri Enstitüsü, Doktora Tezi, İstanbul.

Şentürk, U., Yılmaz, A., \& Gönener, U. (2015). Okul öncesi dönemde motor gelişime yönelik hareket eğitimi ve oyun çalışmalarının içerik analizi. Spor Yönetimi ve Bilgi Teknolojileri, 10(2).

Sevim, Y. (2002). Antrenman Bilgisi Kitabı. Ankara: Nobel Yayın Dagıtım.

Sevindik, F. (2011). Fırat Üniversitesi Öğrencilerinde Problemli İnternet Kullanımı Ve Să̆lıklı Yaşam Biçimi Davranışlarının Belirlenmesi (Doktora tezi). Halk Sağlığı Ana Bilim Dalı, Malatya.

Sternberg, R. J., \& Williams, W. M. (2002). Educational Psychology. Allyn and Bacon, USA.

Tamer, K. (1987). Beden Ĕğitimi ve Oyun Öğretimi. Anadolu Üniversitesi, Açıköğretim Fakültesi Ders Kitabı, Meteksan Ltd. Şti., Ankara.

Tekkurşun-Demir, G., \& Cicioğlu, H. İ. (2018). Fiziksel Aktiviteye Katılım Motivasyonu Ölçeği (FAKMÖ): Geçerlik ve güvenirlik çalışması. International Journal of Human Sciences, 15(4), 2479-2492. https://doi.org/10.14687/jhs.v15i4.5585

Tortop, Y., \& Ocak, Y. (2010). Sinıf öğretmenlerinin eğitsel oyun uygulamalarına yönelik görüşlerinin incelenmesi. Spor ve Performans Araştırmaları Dergisi, 1(1), 14-22.

Tümer, A. (2007). Fiziksel Aktiviteyi Artırmada Değişim Aşaması Temelli Bireysel Danışmanlık Girişiminin Etkililiği. Ege Üniversitesi, Sağlık Bilimleri Enstitüsü, Hemşirelik Programı, Doktora Tezi, İzmir.

Tunay, B. V. (2008). Yetişkinlerde Fiziksel Aktivite. Hacettepe Üniversitesi Sağlık Bilimleri Fakültesi Fizik Tedavi ve Rehabilitasyon Bölümü. Ankara: Klasmat Matbaacılık

Türkeli, A., \& Namlı, S. (2019). Beden Eğitimi Ve Spor Bölümü Öğrencilerinin Fiziksel Aktivite Motivasyonlarinin Incelenmesi, Iksad 4. International Congress of Social Sciences.

Vassigh, G. (2012). Üniversite Öğrencilerinin Fiziksel Aktivite Durumları ile Sağllklı Beslenme İndekslerinin Değerlendirilmesi. Yayımlanmamış Yüksek lisans Tezi, Hacettepe Üniversitesi Sağlık Bilimleri Enstitüsü, Ankara.

Viau, R. (2015). Okulda motivasyon okulda güdüleme ve güdülenmeyi öğrenme (Y. Budak. Çev.). Ankara: Anı yayınevi.

Vural, Ö. (2010). Masa başı çalışanlarda fiziksel aktivite düzeyi ve yaşam kalitesi ilişsisi. Yüksek Lisans Tezi, Ankara; Gazi Üniversitesi, Sağlık Bilimleri Enstitüsü, Beden Eğitimi ve Spor Anabilim Dalı. https://doi.org/10.1501/Sporm_0000000178

Yalçın, İ., Turğut, M., Gacar, A., \& Çalık, F. (2017). Beden Eğitimi ve Spor Yüksekokulu'nda Öğrenim Gören Kadın Sporcuların Spora Katılım Motivasyonlarının Bazı Değişkenlere Göre Araştırılması. Uluslararası Kültürel ve Sosyal Araştırmalar Dergisi (UKSAD), 3(Special Issue 2), 201-210.

Yılmaz, A., Karakaş, G., Baba-Kaya, H., \& Kaçay, Z. (2017). The effects of sportive exercises on physical fitness of children with specific learning disability. Acta Kinesiologica, 11(1), 88-93.

Zorba, E., \& Saygın, Ö. (2013). Fiziksel Aktivite ve Fiziksel Uygunluk. Ankara, Firat Matbaac1lık. 


\section{Copyrights}

Copyright for this article is retained by the author(s), with first publication rights granted to the journal.

This is an open-access article distributed under the terms and conditions of the Creative Commons Attribution license (http://creativecommons.org/licenses/by/4.0/). 